\title{
Efficacy of Trichoderma against Sclerotium rolfsii causing collar rot disease of lentil under in vitro conditions
}

\author{
Shiva Kant Kushwaha*, Sanjeev Kumar and Balkishan Chaudhary \\ MP-482004, INDIA \\ *Corresponding author. E-mail: sanjeevcoa@gmail.com \\ Received: June 30, 2017; Revised received: November 1, 2017; Accepted: February 5, 2018
}

Department of Plant Pathology, College of Agriculture, Jawaharlal Nehru Krishi Vishwa Vidyalaya, Jabalpur,

\begin{abstract}
Three biocontrol agents viz., Trichoderma viride, T. virens and T. harzianum were evaluated to test the antagonism against Sclerotium rolfsii under in vitro conditions. All the three antagonists' viz., T. viride, T. virens and $T$. harzianum have shown the potential of parasitizing the growth of Sclerotium rolfsii in vitro. The rate of inhibition was fastest in $T$. harzianum $(63.60 \%)$ followed by $T$ virens $(51.5 \%)$. Least inhibition was recorded in $T$. viride $(50.85 \%)$ after 72 hours of incubation. However, $T$. viride showed the highest $(91.31 \%)$ reduction in sclerotia formation followed by $T$. harzianum $(84.92 \%)$ and $T$. virens $(84.29 \%)$ after 15 days of incubation. The volatile compounds from Trichoderma viride were found most effective in suppressing the mycelial growth (51.11\%) and sclerotia production $(95.90 \%)$ of the target pathogen. The culture filtrate from both $T$. harzianum and $T$. viride $(15 \%$ concentration) was found very effective in inhibiting the radial growth (57.46 and $49.62 \%)$ and sclerotia formation (98.20 and $99.83 \%$ ) of Sclerotium rolfsii. The antagonists such as T. harzianum and T. viride can be used as a bio-control agent against $S$. rolfsii under field condition.
\end{abstract}

Keywords: Collar rot, Efficacy, Lentil, Sclerotium rolfsii, Trichoderma

\section{INTRODUCTION}

Lentil production in India has always been important as it is one of the most important Rabi crops in the country. Lentil has potential to grow in dry land areas. It is also used as a cover crop to check the soil erosion and is grown throughout the northern and central India. In India, it occupies an area of $1.48 \mathrm{~m}$ ha and contributes $1.03 \mathrm{~m} \mathrm{t}$ to pulse production with the productivity of $697 \mathrm{~kg}$ ha-1. It is mainly cultivated in Madhya Pradesh, Uttar Pradesh, Bihar, and West Bengal, which account for $85 \%$ of total production (Anonymous, 2015). The crop is both cultivated as a primary crop as well as a secondary crop in the districts like Sagar, Jabalpur, Bundelkhand and Bhopal in Madhya Pradesh. However, in Madhya Pradesh, lentil yield potential is far below $(711.93 \mathrm{~kg} / \mathrm{ha})$ than the other cereal crops (Mondal et al., 2013). Various causes are associated with its low yield. One of them is the diseases causing remarkable yield loss. Lentil suffers from an attack of a number seed borne diseases such as vascular wilt, collar rot, root rot, stem rot, rust, powdery mildew and downy mildew, which are caused by Fusarium oxysporum f.sp. lentis, Sclerotium rolfsii, Rhizoctonia solani, Uromycis fabae, Erysiphe polygoni and Peronospora lentis, respectively (Khalequzzaman, 2016 ). Among the diseases, collar rot caused by $S$. rolfsii which is gaining importance. $S$. rolfsii is an eco- nomically important pathogen on numerous crops worldwide. It has an extensive host range; at least 500 species in 100 families are susceptible, the most common hosts are legumes, crucifers and cucurbits, and commonly occurs in the tropics, subtropics, and other warm temperate regions (Hemanth et al., 2016). Management of soil borne plant pathogens including $S$. rolfsii can be achieved by different fungicides, soil fumigants (Methyl bromide) and bioagents. Frequent application of fungicides causes environmental pollution therefore there is a need to reduce the amount of chemicals applied to soil (Hemanth et al., 2016). The fast growth of the $S$. rolfsii and its capability of producing excessive sclerotia that may persist in soil for several years (Singh et al., 2012). Hence management of $S$. rolfsii causing collar rot of lentil is difficult to achieve chemically, In this context bioagents can be used as an alternative source for controlling soil-borne diseases since they comprise a rich source of bioactive substance ((Jegathambigai et al., 2010). Biological control of plant diseases has been the subject of extensive research in the last two decades. Trichoderma spp. is well documented as effective biological control agents of plant diseases (Sain and Pandey, 2016). Therefore, the present investigation was carried out to evaluate the Trichoderma against $S$. rolfsii causing collar rot of lentil. 


\section{MATERIALS AND METHODS}

The experiments were conducted in the Department of Plant Pathology J.N.K.V.V. Jabalpur (M.P.) during 2015-16. Three biocontrol agents viz., Trichoderma viride, $T$. virens and $T$. harzianum were evaluated to test the antagonism against $S$. rolfsii causing collar rot of lentil.

Growth of antagonist and the pathogen in monoculture and dual culture: To study the growth of antagonists and the test fungus in monoculture, 5 mm mycelial discs of $T$. viride, $T$. virens, $T$. harzianum and $S$. rolfsii were inoculated centrally on sterilized potato dextrose agar in Petri-dishes. Then plates were incubated in BOD incubator at $28 \pm 1^{0} \mathrm{C}$. Observations on colony diameter of individual antagonist and the pathogen were recorded after $72 \mathrm{hrs}$ of incubation. For screening of the antagonists against $S$. rolfsii, dual culture technique developed by Mortan and Straube, (1955) was adopted. Observation on colony diameter of bioagents and test fungus was recorded. Inhibition of mycelial growth of test pathogen over check was calculated by the formula given by Vincent (1947).

$\mathrm{I}(\boldsymbol{\mathbf { O }}) \mathbf{=}(\mathrm{C}-\mathrm{T}) / \mathrm{C} * \mathbf{1 0 0}$

Where, $\mathrm{I}=$ percent inhibition, $\mathrm{C}=$ colony diameter in control, and $\mathrm{T}=$ Colony diameter in treatment

Re-isolation was done by transferring $5 \mathrm{~mm}$ mycelial disc cut by cork borer from the zone where the test fungus was already overgrown by the antagonist on PDA medium to study the viability of test fungus

Effect of volatile and non volatile compounds from antagonist(s) on the radial growth of $\boldsymbol{S}$. rolfsii: The effect of volatile compounds from $T$. viride, $T$. virens and $T$. harzianum on radial growth of $S$. rolfsii was followed as per the method given by Dennis and Webster (1971a and b). The two bottom portion of petriplates containing PDA were inoculated with a $5 \mathrm{~mm}$ disc of pathogen and antagonist, respectively and both inoculated bottom plates were placed facing each other and sealed with cellophane adhesive tape. The petriplate containing PDA without antagonist serves as control. The observations on the radial growth of the test fungus were recorded after 3 days and formation of sclerotia after 15 days of incubation at $28 \pm 1^{\circ} \mathrm{C}$.

To study the effect of non volatile compounds, the biocontrol agents were grown in Potato dextrose broth at $27^{\circ} \mathrm{C}$ with intermittent shaking at $150 \mathrm{rpm}$. The metabolites were collected after 15 days and filtered. The sterilized filtrate was amended in PDA to make 5, 10 and $15 \%$ concentration in petriplates. The solidified agar plates in triplicates were inoculated at the centre with $5 \mathrm{~mm}$ diameter mycelial disc of the pathogen and incubated at $28^{\circ} \mathrm{C}$ for 3 days. The Plates without filtrate served as control. The Colony diameter and sclerotia formation were measured (Chaurasia et al., 2013) and percent inhibition of radial growth and sclerotia formation was calculated using the formula given by Vincent 1947.

\section{RESULTS}

In monoculture, $T$. viride showed $90 \mathrm{~mm}$ growth on PDA after $72 \mathrm{hrs}$ of incubation followed by $T$. virens and $T$. harzianum which exhibited $87.33 \mathrm{~mm}$ and $86.50 \mathrm{~mm}$ colony diameter, respectively. $S$. rolfsii showed $89.33 \mathrm{~mm}$ growth on PDA after $72 \mathrm{hrs}$ of incubation. In dual culture, all the three antagonists' viz.,

Table 1. Effect of Trichoderma on growth and sclerotia formation of S. rolfsii.

\begin{tabular}{|c|c|c|c|c|c|c|}
\hline & Monoculture & t. & al culture & & & \\
\hline Treatment & $\begin{array}{l}\text { Colony } \\
\text { diameter } \\
(\mathbf{m m})^{*}\end{array}$ & $\begin{array}{l}\text { Colony diameter } \\
\text { of antagonist } \\
(\mathrm{mm}) *\end{array}$ & $\begin{array}{l}\text { Colony diame- } \\
\text { ter of Pathogen } \\
(\mathrm{mm}) *\end{array}$ & $\begin{array}{l}\text { Growth } \\
\text { Inhibition } \\
(\%) \\
\end{array}$ & $\begin{array}{l}\text { No. of } \\
\text { sclerotia } \\
\text { formed } \\
\end{array}$ & $\begin{array}{l}\text { Sclerotia } \\
\text { Inhibiton } \\
\text { over contol }\end{array}$ \\
\hline Trichoderma viride & 90.00 & 45.76 & 44.23 & 50.85 & 36.66 & 91.31 \\
\hline Trichoderma virens & 87.33 & 46.83 & 43.16 & 51.55 & 66.33 & 84.29 \\
\hline Trichoderma harzianum & 86.50 & 56.46 & 33.53 & 63.60 & 63.66 & 84.92 \\
\hline Sclerotium rolfsii & 89.33 & & 36.86 & - & 422.33 & \\
\hline $\mathrm{CD}(0.05)$ & 2.358 & & 2.556 & & 3.619 & \\
\hline
\end{tabular}

*Average of 3 replication

Table 2. Effect of volatile and non-volatile compounds from Trichoderma on radial growth of Sclerotium rolfsii after three days of incubation.

\begin{tabular}{|c|c|c|c|c|c|c|c|c|}
\hline \multirow[b]{3}{*}{ Treatment } & \multicolumn{2}{|c|}{ Volatile compounds } & \multicolumn{6}{|c|}{ Non - volatile compounds } \\
\hline & \multirow[b]{2}{*}{$\begin{array}{l}\text { Radial } \\
\text { growth of } \\
\text { mycelium } \\
(\mathrm{mm})^{*}\end{array}$} & \multirow[b]{2}{*}{$\begin{array}{c}\text { Growth } \\
\text { inhibition } \\
(\%)\end{array}$} & \multicolumn{2}{|c|}{$5 \%$} & \multicolumn{2}{|c|}{$10 \%$} & \multicolumn{2}{|c|}{$15 \%$} \\
\hline & & & $\begin{array}{c}\text { Myceli- } \\
\text { algrowth of } \\
\text { pathogen } \\
(\mathrm{mm}) * \\
\end{array}$ & $\begin{array}{l}\text { Growth } \\
\text { Inhibi- } \\
\text { tion (\%) }\end{array}$ & $\begin{array}{c}\text { Myceli- } \\
\text { algrowth of } \\
\text { pathogen } \\
(\mathrm{mm})^{*}\end{array}$ & $\begin{array}{c}\text { Growth } \\
\text { Inhibi- } \\
\text { tion } \\
(\%) \\
\end{array}$ & $\begin{array}{c}\text { Myceli- } \\
\text { algrowth of } \\
\text { pathogen } \\
(\mathrm{mm}) *\end{array}$ & $\begin{array}{c}\text { Growth } \\
\text { Inhibi- } \\
\text { tion (\%) }\end{array}$ \\
\hline Trichoderma harzianum & 54.00 & 40.00 & 87.33 & 02.33 & 77.50 & 13.24 & 38.00 & 57.46 \\
\hline Trichoderma viride & 44.00 & 51.11 & 89.00 & 00.36 & 82.50 & 07.64 & 45.00 & 49.62 \\
\hline $\begin{array}{l}\text { Trichoderma } \\
\text { Virens }\end{array}$ & 45.00 & 50.00 & 89.00 & 00.36 & 83.16 & 06.90 & 65.66 & 26.49 \\
\hline Sclerotium rolfsii & 90.00 & -- & 89.33 & -- & 89.33 & -- & 89.33 & -- \\
\hline $\mathrm{CD}(0.05)$ & 2.325 & & $\mathrm{~N} \backslash \mathrm{A}$ & & 3.195 & & 3.436 & \\
\hline
\end{tabular}


Shiva Kant Kushwaha et al. / J. Appl. \& Nat. Sci. 10(1): 307 - 312 (2018)

Table 3. Effect of volatile and non-volatile compounds from Trichoderma on Sclerotia formation of Sclerotium rolfsii after fifteen days of incubation.

\begin{tabular}{|c|c|c|c|c|c|c|c|c|}
\hline \multirow[b]{3}{*}{ Treatment } & \multicolumn{2}{|c|}{ Volatile compounds } & \multicolumn{6}{|c|}{ Non - volatile compounds } \\
\hline & \multirow[b]{2}{*}{$\begin{array}{l}\text { No. of sclero- } \\
\text { tia formed } \\
(15 \text { DAI })^{*}\end{array}$} & \multirow[b]{2}{*}{$\begin{array}{c}\text { Sclerotia } \\
\text { inhibition } \\
(\%)\end{array}$} & \multicolumn{2}{|c|}{$5 \%$} & \multicolumn{2}{|c|}{$10 \%$} & \multicolumn{2}{|c|}{$15 \%$} \\
\hline & & & $\begin{array}{c}\text { No. of scle- } \\
\text { rotia } \\
\text { formed } \\
(15 \text { DAI })^{*} \\
\end{array}$ & $\begin{array}{c}\text { Sclerotia } \\
\text { inhibition } \\
(\%)\end{array}$ & $\begin{array}{c}\text { No. of } \\
\text { sclerotia } \\
\text { formed } \\
(15 \text { DAI })^{*}\end{array}$ & $\begin{array}{c}\text { Sclerotia } \\
\text { inhibi- } \\
\text { tion }(\%)\end{array}$ & $\begin{array}{c}\text { No. of } \\
\text { sclerotia } \\
\text { formed } \\
\text { (15 DAI)* }\end{array}$ & $\begin{array}{c}\text { Sclerotia } \\
\text { inhibition } \\
(\%)\end{array}$ \\
\hline $\begin{array}{l}\text { Trichoderma } \\
\text { harzianum }\end{array}$ & 218.00 & 49.49 & 598.66 & 02.44 & 196.33 & 68.00 & 11.00 & 98.20 \\
\hline $\begin{array}{l}\text { Trichoderma } \\
\text { viride }\end{array}$ & 17.66 & 95.90 & 602.66 & 01.79 & 319.66 & 47.90 & 01.00 & 99.83 \\
\hline $\begin{array}{l}\text { Trichoderma } \\
\text { Virens }\end{array}$ & 151.66 & 64.86 & 581.66 & 05.21 & 302.66 & 50.67 & 113.33 & 81.53 \\
\hline $\begin{array}{l}\text { Sclerotium rolfsii } \\
\mathrm{CD}(0.05)\end{array}$ & $\begin{array}{c}431.66 \\
4.167\end{array}$ & -- & $\begin{array}{c}613.66 \\
3.744\end{array}$ & -- & $\begin{array}{c}613.66 \\
2.921\end{array}$ & -- & $\begin{array}{c}613.66 \\
2.972\end{array}$ & -- \\
\hline
\end{tabular}
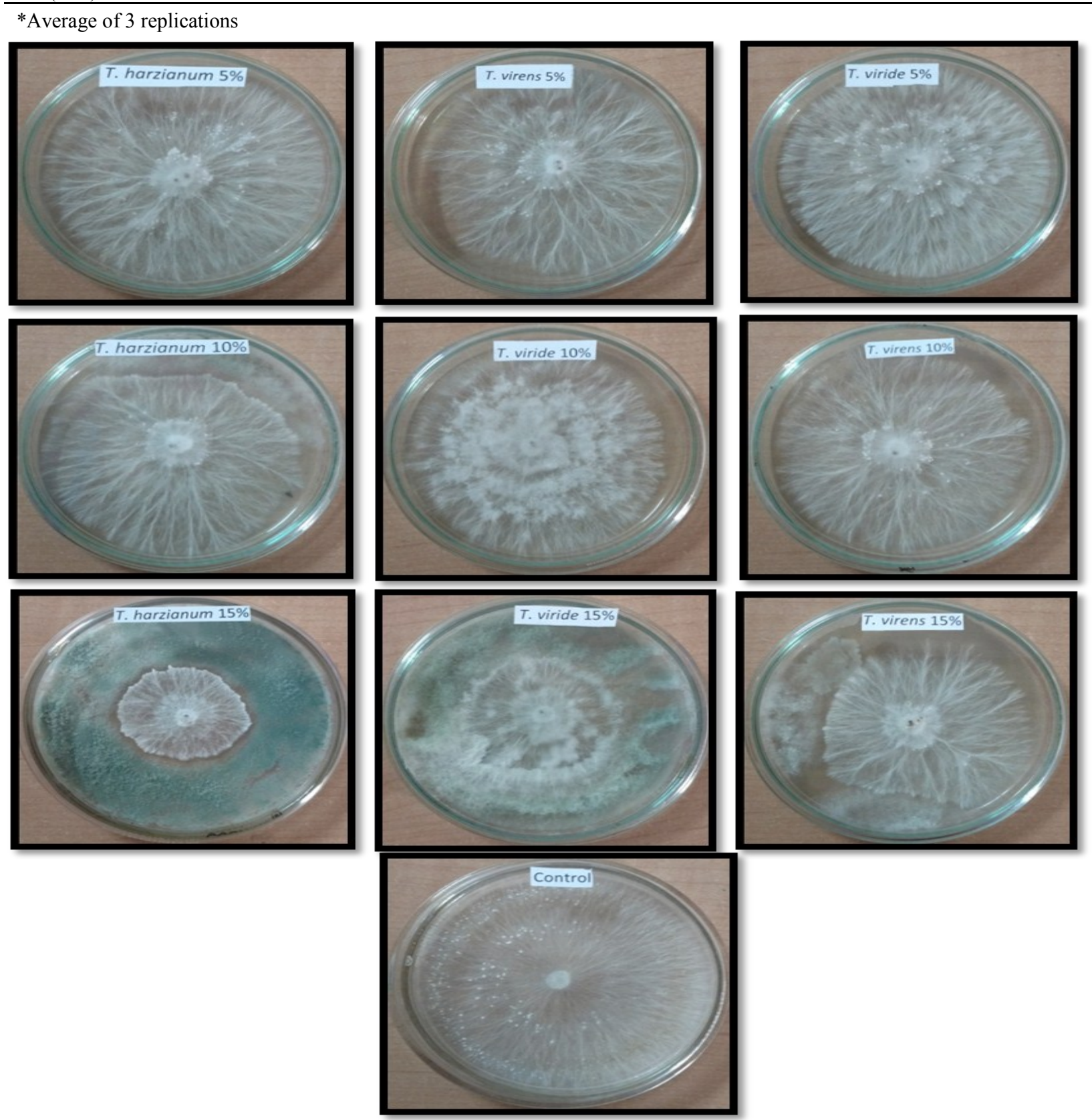

Plate 1. Effect of non - volatile compounds from Trichoderma on radial growth of Sclerotium rolfsii. 
Shiva Kant Kushwaha et al. / J. Appl. \& Nat. Sci. 10(1): 307 - 312 (2018)
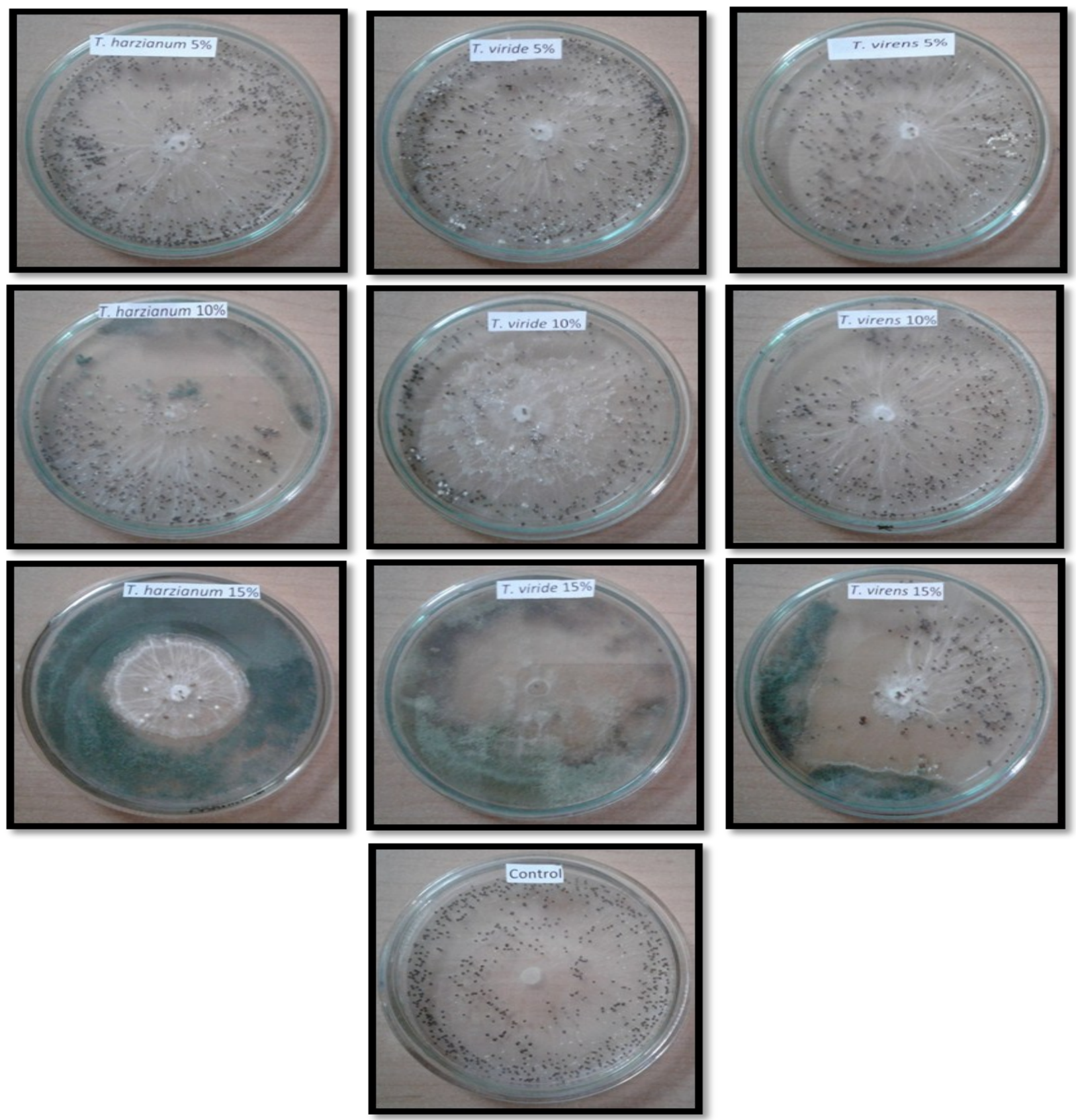

Plate 2. Effect of non - volatile compounds from Trichoderma on sclerotia formation of Sclerotium rolfsii.

$T$. viride, T. virens and T. harzianum have shown the potential of parasitizing the growth of Sclerotium rolfsii in vitro. The rate of inhibition was fastest in $T$. harzianum $(63.60 \%)$ followed by $T$. virens $(51.5 \%)$ and $T$. viride $(50.85 \%)$ after 72 hours of incubation. However, T. viride showed the highest (91.31\%) reduction in sclerotia formation followed by $T$. harzianum $(84.92 \%)$ and $T$. virens $(84.29 \%)$ after 15 days of incubation (Table-1).

The effect of volatile compounds from Trichoderma species on the growth and sclerotia formation of Sclerotium rolfsii revealed that all the Trichoderma species produced toxic volatile metabolites having significant effect in reducing the radial growth and sclerotia formation of the test pathogen. The volatile metabolites from Trichoderma viride were most effective in inhibiting the mycelial growth $(51.11 \%)$ and sclerotia production $(95.90 \%)$ followed by $T$. virens $(50 \%$ and $64.86 \%)$. The least inhibition of mycelia growth (40 $\%)$ and sclerotia production (54\%) was recorded in $T$. harzianum (Table-2). The non-volatile compounds from all the three Trichoderma species at 5 and $10 \%$ concentration were found not effective in inhibiting the radial growth and sclerotia formation of $S$. rolfsii however, were found very effective at $15 \%$ percent concentration. The non volatile metabolites from $T$. harzi- 
anum at $15 \%$ percent concentration was most effective in inhibiting the mycelial growth $(57.46 \%)$ of target pathogen followed by $T$. viride $(49.62 \%)$. The least inhibition of mycelial growth $(26.49 \%)$ was recorded in $T$. virens. However, the non volatile metabolites from $T$. viride at $15 \%$ percent concentration were most effective in inhibiting the sclerotia production $(99.83 \%)$ of target pathogen followed by $T$. harzianum $(98.20 \%)$. But they were significantly at par with each other. The least inhibition of sclerotia production $(81.53 \%)$ was recorded in $T$. virens (Table-2, Plates-1 and 2 ).

\section{DISCUSSION}

Antagonisim of Trichoderma species against several pathogens were reported by Reddy et al. (2013), Sundara moorthy and Balabaskar (2013), Hanan and Mohamed (2014). The degree of inhibition varied from one strain to another. Species of Trichoderma have been demonstrated in vitro to act against fungal plant pathogens by producing diffusible volatile antibiotics. Vey et al. (2001) reported that there are large varieties of volatile secondary metabolites produced by Trichoderma such as ethylene, hydrogen cyanide, aldehydes and ketones which play an important role in controlling the plant pathogens (Bhagat et al., 2014). Similarly, Amin et al., (2010) reported volatile activity of six isolates of Trichoderma spp. against seven different fungal plant pathogens. Among the six Trichoderma isolates studied, $T$. viride (Tv-1) was found to most effective in reducing the mycelial growth of $F$. oxysporum $(41.8 \%)$. S. rolfsii mycelium growth and sclerotial production were inhibited by 40.68 and $48.1 \%$, respectively. In case of $R$. solani, T. viride (Tv-2) accounted for maximum reduction in mycelial growth $(30.58 \%)$ and sclerotial parasitization (65.6\%). Several workers like Pan and Bhagat (2008), Stoppacher et al. (2010) and Pan et al. (2013) have also reported the effectiveness of diffusible volatile compounds by $T$. viride and $T$. harzianum under in vitro. Antifungal volatile compounds produced by strain SQR-T037 highly effective to suppress the growth of $F$. oxysporum up to 9 days causing watermelon wilt (Waseem et al., 2013) In the present investigation, $T$. viride and $T$. harzianum were highly efficient whereas $T$. virens have exhibited relatively less inhibition of mycelial growth of test fungus. The possible reason may be due to their inherent potentiality to adapt well in introduced conditions and aggressiveness of the Trichoderma isolates towards certain plant pathogens (Pan and Jash, 2009). Several workers studied on the production of volatile and non-volatile antibiotics revealed that $T$. harzianum and $T$. viride were highly effective in reducing the radial growth of $S$. rolfsii by the production of these substances (Rao and Kulkarni, 2003). Dubey and Suresh (2006) found that nonvolatile substances produced by $T$. harzianum are in- hibitory to $F$. o. $f$. $s p$. ciceri causing chickpea wilt. Similarly, $T$. viride isolate, followed by $T$. harzianum inhibited maximum mycelial growth of the $F$. o. f. $s p$. ciceri through production of volatile and non-volatile inhibitors in dual culture (Dubey et al., 2007). Waseem et al., (2013) reported that nonvolatile antifungal compounds extracted from the liquid culture Trichoderma strain SQRT037, significantly inhibited the growth of $F$. oxysporum. f.sp. niveum incitant watermelon of wilt. Nagamani et al. (2017) reported that Trichoderma, spp. are the most promising and effective bioagents against many plant pathogenic fungi. They screened twenty Trichoderma isolates for their efficacy against soil borne plant pathogens namely $R$. bataticola, $F$. oxysporum ciceri and $S$. rolfsii in chickpea. The isolates T. asperellum (ATPU 1), T. harzianum (ATPP 6), T. asperelum (KNO 2), T. asperellum (KNPG 3) were most efficient in the production of volatile and non-volatile compounds.

\section{Conclusion}

From the in vitro findings, it can be suggested that the antagonists such as Trichoderma harzianum and Trichoderma viride can be used as a bio-control agent against Sclerotium rolfsii under field condition. It is also revealed that the microorganisms that naturally remain in the soil are having more or less similar potential antagonistic effect on the various crop disease caused by various pathogens. And some of them can be used as a potential bio- control agent under field condition to decrease the disease incidence and to increase crop productivity. Therefore, further work should be taken up to explore the possibility of the use of the antagonists under study in field condition for the biological control of the diseases caused by Sclerotium rolfsii.

\section{REFERENCES}

Amin F., Razdan V. K., Mohiddin F. A., Bhatt K. A., and Sheikh P. A. (2010). Effect of volatile metabolites of Trichoderma species against seven fungal plant pathogens in-vitro. Journal of Phytology 2(10): 34-37.

Amin, F., Razdan, V. K., Bhat, F. A. and Saba, B. M. K. (2010). Potential of Tricoderma species as biocontrol agents of soil borne fungal propagules. Journal of Phytology 2(10): 38-41.

Anonymous. (2015). Area and production of India. http:// indiastat.com.

Bhagat, S., Birah, A., Kumar, R., Yadav, M.S. and Chattopadhyay, C. (2014). Plant disease management: prospects of pesticides of plant origin. Advances in Plant Biopesticides. 119-129.

Chaurasia, S., Chaurasia. A.K., Chaurasia, S. (2013). Factors affecting the growth and sclerotial production in Sclerotium rolfsii causing foot rot of brinjal. Ind. J Fund. \& Appl. Life Sci. 3(2): 73-84.

Dennis, C. and Webster, J. (1971a). Antagonistic properties of species groups of Trichoderma II. Production of 
volatile antibiotics. Trans. Brit. Mycol. Soci. 57: 41-48.

Dennis, C. and Webster, J. (1971b). Antagonistic properties of species groups of Trichoderma I. Production of non volatile antibiotics. Trans. Brit. Mycol. Soci 57: 25-39.

Dubey, S. C. Suresh, M. and Singh, B. (2007). Evaluation of Trichoderma species against Fusarium oxysporum f.sp. ciceris for integrated management of chickpea wilt. Biological Control. 40: 118-127.

Dubey, S.C. and Suresh, M. (2006). Randomly amplified polymorphic DNA markers for Trichoderma species and antagonism against Fusarium oxysporum f. sp. Ciceris causing chickpea wilt. Journal of Phytopathology. 154: 663-669.

Hanan, I. M. and Mohamed, O. I. (2014). The efficacy of Trichoderma species and Bacillus isolates in the control of chickpea wilt pathogens. Agriculture, Forestry and Fisheries. 3(5): 346-351.

Hemanth, G., Kumar P. K. R., Niharika P. S. and kolli, S. K. (2016). Fungicides effect on soil micro flora in Tekkali Mandal, Srikakulam (Dist.). International Journal of Research and Development in Pharmacy and Life Sciences. 5(4): 2245-2250.

Jegathambigai, V., R. S. Wijeratnam W. and Wijesundera, R.L.C. (2010). Effect of Trichoderma sp. on Sclerotium rolfsii, the causative agent of collar rot on Zamioculcas zamiifolia and an on farm method to mass produce Trichoderma species. Plant Pathology Journal, 9 (2): 47-55.

Khalequzzaman, K. M. (2016). Control of foot and root rot of lentil by using different management tools. $A B C$ Journal of Advanced Research. 5(1): 2312-203.

Mondal, M. M. A., Puteh, A. B., Malek, M. A. and Kabir, A. K. M. R. (2013b). Flowering pattern and reproductive efficiency in lentil. Legume Research, 36: 153-157.

Mortan, D. T. and Straube, N. H. (1955). Antagonistic and stimulatory effects of micro organis Sclerotium rolfsii. Phytopathology 45: 419-420.

Agamani, P., Bhagat, S., Biswas, M. K. and Viswanath, K. (2017). Effect of Volatile and Non Volatile Compounds of Trichoderma spp. against soil borne diseases of chickpea. Int. J. Curr. Microbiol. App. Sci. 6(7):14861491.

Pan, S. and Bhagat, S. (2008). Characterization of antagonistic potential of Trichoderma species against some soil borne plant pathogens. Journal of Biological Control.
22: 43-49.

Pan, S. and Jash, S. (2009). Production and regulation of cell wall degrading hydrolytic enzymes in mycoparasitic Trichoderma species. Journal of Mycology and Plant 39 (2): $208-215$

Pan, S., Mukherji R. and Bhagat, S. (2013). Evaluation of Trichoderma species against soil borne plant pathogens. Annals of Plant Protection Sciences. 21(1): 176-223.

Reddy, N. G., Thahir, B. S. and. Eswara, R. N. P. (2013). Evaluation of Trichoderma Sp. against Rhizoctonia bataticola Causing Dry Root Rot of Chick Pea (Cicer arietinum L.).Progressive Research 8: 572-574.

Rao, S. N. and Kulkarni, S. (2003). Effect of Trichoderma spp. on growth of Sclerotium

rolfsii Sacc. Journal of Biological Control, 17: 181-184

Sain, S. K. and Pandey, A.K. (2016). Spectrum of three isolates of Trichoderma harzianum Rifai against important fungal diseases of tomato. $6^{\text {th }}$ International Conference Plant Pathogens and People. Feb.23-27, New delhi, India.

Singh, S.R., Singh, S.K. and Pandey, R.K. (2012). Integrated management of collar rot of lentil caused by Sclerotium rolfsii. International Journal of Plant Protection. 5(2): 386-390.

Stoppacher, N., Kluger, B., Zeilinger, S., Krska, R. and Schuhmacher, R. (2010). Identification and profiling of volatile metabolites of the biocontrol fungus Trichoderma atroviride by HS-SPME-GCMS. Journal of Microbiology and Methods. 81(2): 187-193.

Sundara Moorthy, S. and Bala Baskar, P. (2013). Biocontrol efficacy of Trichoderma species against wilt of tomato caused by Fusarium oxysporum f. sp. lycopersici. Journal of Applied Biology and Biotechnology. 1(3): 36-40.

Vey, A., Hoagland, R., E. and Butt, T. M. (2001). Toxic metabolites of fungal biocontrol agents. Fungi as biocontrol agents: Progress, Problems and Potential. Butt, T.M., Jackson, C.N. (Eds). 311-346 CAB international, Bristol.

Vincent, J. M. (1947). Distortion of fungal hyphae in presence of certain inhibitors. Nature, 154: 850 .

Waseem, R., Muhammad, F., Sohail, Y., Faheem, U. R. and Muhammad, Y. (2013). Volatile and nonvolatile antifungal compounds produced by Trichoderma harzianum SQR-T037 suppressed the growth of Fusarium oxysporum f. sp. niveum. Science letters. 1(1): 21-24. 